\title{
A developmental study of long-term memory in the perception of apparent movement'
}

LARRY M. RASKIN

PURDUE UNIVERSITY

The long-term influence of prior experience with either apparent movement or nonmovement upon the later perception of movement was studied with groups of Ss aged 6-9, 9-9. 12-9, and 19-7. Significant differences owing to type of prior experience were found within each age group. A form previously seen as moving continued to be seen as moving when later presented in sequence with a dissimilar form, a condition in which apparent movement is not usually seen. $A$ form previously seen as stationary continued to be seen as stationary when later presented in sequence with an identical form, a condition in which apparent movement is usually seen. No developmental trends were present.

There have been several developmental studies of the perception of apparent movement (Meili \& Tobler, 1931; Gantenbein, 1952; Brenner, 1957; Pollack, 1966). For the most part, these have dealt with physical parameters of the illusion such as threshold determination and range of movement, and how these factors vary with age. The present developmental study investigated the influence of long-term memory on the perception of apparent movement.

A basic factor in the perception of apparent movement is the similarity or difference in shape of the stimulus forms used to produce the illusion. If the two forms that are presented in sequence are identical or very similar, movement from one position to the other is usually seen (Orlansky, 1940; Squires, 1959). However, Raskin (1966) reported that specific training and the subsequent memory traces may negate the effect of either similarity or difference in shape. Adult Ss who were given prior experience with a form in apparent movement later saw that form move when it was presented in sequence with a very dissimilar form. Control Ss without the same training did not see this movement. Other Ss were given preliminary training with dissimilar forms presented in the apparent movement paradigm; two successively-presented stationary forms were seen. Later, the initial form was presented in sequence with an identical form but these Ss did not see movement. The effects of the training in both of the situations were long lasting; they were present as long as one week after training. These results were interpreted in terms of perceptual learning. The study reported here is an investigation of the influence of long-term memory on the perception of apparent movement by Ss of various ages.

\section{Method}

Ninety-six Ss, 24 from each of four age groups, were tested individually. ${ }^{2}$ Mean ages of the groups were $6-9,9-9,12-9$, and $19-7$.
The stimulus forms and apparatus are described in detail elsewhere (Raskin, 1966). Pairs of white forms were presented on $16 \mathrm{~mm}$ motion picture film in left then right sequences. Each pair of forms, two identical arrows or an arrow and a square, was shown 30 consecutive times. Projected at 24 frames/sec, each presentation of either pair consisted of a $51 \mathrm{msec}$ exposure of the left form (arrow) followed $5.4 \mathrm{msec}$ later by the right form (arrow or square), and then by $1-1 / 4$ sec of blank film, which provided the interrepetition interval. Each form had a projected length of $3-1 / 2$ in., and the spatial separation between the left and right forms, if both had been presented simultaneously, was also $3-1 / 2$ in. The fixation point, a 1-1/2 in. diameter black circle, was attached to the screen $1 / 2$ in. below the lower left border of the left stimulus form. The $\mathrm{S}$ was seated $11 \mathrm{ft}$ from the screen.

\section{Procedure}

Testing took place in a darkened room. Each $\mathrm{S}$ was given a training session and $24 \mathrm{~h}$ later, a test session. The $\mathrm{S}$ was told that he was going to be shown a movie film and to try to see what was in the film while keeping his eyes on the black circle. Younger Ss were told that they were playing a game.

After 3 min of dark adaptation, each $\mathrm{S}$ was shown either the training or test series. He was then asked what he had seen and to demonstrate it at the screen. Verbal reports were recorded verbatim, and were classified as to whether movement was seen or not. The demonstrated report was used to check the verbal response, and was given priority in the three cases in which the reports were conflicting or the verbal report unclear. Two of the youngest Ss were asked to draw what they had seen because their other reports were equivocal.

The Ss at each age level were divided into two equal groups. One group at each age level received preliminary training with 30 repetitions of the arrow-arrow series and was tested with the arrow-square sequences. The other group at each age level was given arrowsquare training and tested with the arrow-arrow series. After the test session, prizes of inexpensive toys were chosen by the younger Ss. Ball point pens were given to the older ones.

\section{Resulis and Discussion}

The number of Ss in each group who reported movement in the pairs of forms was recorded and these data were analyzed using Chi-square with Yates's correction for continuity. The results shown in Table 1 are the number of reports of movement and no movement in the arrow-square series at each age level. 
Table 1

Number of Reports of Arrow-to-Square Movement

\begin{tabular}{clrrr} 
& & \multicolumn{2}{c}{ Reports } & \\
\cline { 3 - 4 } Age Level & Training Group & Movt. & None & Chi-square \\
\hline \multirow{2}{*}{$6-9$} & Identical Forms & 8 & 4 & \multirow{2}{*}{$9.19^{*}$} \\
\multirow{2}{*}{$9-9$} & Dissimilar Forms & 0 & 12 & \\
\multirow{2}{*}{$12-9$} & Identical Forms & 10 & 2 & \multirow{2}{*}{$13.89^{* *}$} \\
\multirow{2}{*}{$19-7$} & Dissimilar Forms & 0 & 12 & \\
& Identical Forms & 9 & 3 & $8.40^{*}$ \\
& Dissimilar Forms & 1 & 11 & \\
\hline
\end{tabular}

$a_{\text {With Yates's correction for continuity, } d f=1}$

$p<.01$

$\rightarrow p<.001$

These are the test results for those Ss with arrowarrow prior experience and the training results without prior experience for the others. The effect of the prior experience with the identical arrows (perceived initially by most of these Ss as a moving arrow-see Table 2 below) was clear. At each age level, significantly more Ss with the prior training saw the arrow move toward the square $(p<.01)$. There were no age differences.

The reports of movement and no movement for the arrow-arrow series are shown in Table 2. These are the test results for $\mathrm{Ss}$ who had preliminary training with the arrow-square sequence and the training results for the other Ss in each age group. The effect of the prior experience with the nonmoving arrow was also clear. Within each group, significantly more Ss who had arrow-square training did not see movement in the arrow-arrow presentation than did those who saw this series first. Again, there were no developmental differences.

The present results confirm that prior experience and long-term memory strongly influence the perception of apparent movement (Raskin, 1966). There were no developmental trends apparent in the data reported here in the long-term memory effects of previously-
Table 2

Number of Reports of Movement in the Arrow-Arrow Series

\begin{tabular}{|c|c|c|c|c|}
\hline \multirow[b]{2}{*}{ Age Level } & \multirow[b]{2}{*}{ Training Group } & \multicolumn{2}{|c|}{ Reports } & \multirow[b]{2}{*}{ Chi-square } \\
\hline & & Movt. & None & \\
\hline $6-9$ & $\begin{array}{l}\text { Identical Forms } \\
\text { Dissimilar Forms }\end{array}$ & $\begin{array}{r}10 \\
2\end{array}$ & $\begin{array}{r}2 \\
10\end{array}$ & $8.17^{* *}$ \\
\hline $9-9$ & $\begin{array}{l}\text { Identical Forms } \\
\text { Dissimilar Forms }\end{array}$ & $\begin{array}{r}11 \\
3\end{array}$ & $\begin{array}{l}1 \\
9\end{array}$ & $8.40^{* *}$ \\
\hline $12-9$ & $\begin{array}{l}\text { Identical Forms } \\
\text { Dissimilar Forms }\end{array}$ & $\begin{array}{r}11 \\
2\end{array}$ & $\begin{array}{r}1 \\
10\end{array}$ & $10.74 * *$ \\
\hline $19-7$ & $\begin{array}{l}\text { Identical Forms } \\
\text { Dissimilar Forms }\end{array}$ & $\begin{array}{r}10 \\
4\end{array}$ & $\begin{array}{l}2 \\
8\end{array}$ & $4.29^{*}$ \\
\hline
\end{tabular}

$a_{W i t h}$ Yates's correction for continuity, $d f=1$

$* 0.05$

$* * 0<.01$

presented visual information. If such age changes do take place, they apparently occur before 6 years of age.

References

BRENNER, M. W. The developmental study of apparent movement. Quart. J. exp. Psychol, 1957, 9, 169-174.

GANTENBEIN, M. Recherches sur le developpement des perceptions: XIV. Recherches sur le developpement de la perception du mouvement avec l'age (mouvement apparent, dit stroboscopique). Arch. Pyychol. Geneve, 1952, 33, 197-294.

MEILI, R., \& TOBLER, E. Les mouvements stroboscopiques chez les enfants. Arch. Psychol. Geneve, 1931, 23, 131-156.

ORLANSKY, J. The effect of similarity and difference in form on apparent visual movement. Arch. Psychol. New York, 1940, No. 246.

POLLACK, R. H. Temporal range of apparent movement as a function of age and intelligence. Psychon. Sci, 1966, 5, 243-244.

RASKIN, L. M. The effect of prior experience on apparent movement. Unpublished doctoral dissertation, McGill University, 1966.

SQUIRES, P. C. Topological aspects of apparent visual motion. Psychol. Forsch, 1959, 26, 1-12.

Notes

1. This research was supported by National Institute of Child Health and Human Development Grant HD-00098 to the Center for Research in Human Learning, University of Minnesota. The author would like to thank Dr. Herbert L. Pick, Jr. for his advice and critical reading of the manuscript.

2. The author is grateful for the cooperation of Dr. Arthur Bergee, Mr. Richard Larson, and Mr. Glenn Matejka of the Centennial School District, Circle Pines, Minnesota, and to Dean Emil Wilken and Mr. Carl Gerber of Anoka-Ramsey State Junior College, Circle Pines, Minnesota. 